\title{
In vitro production of sesquiterpenes by electro-elicitation in Gyrinops walla Gaetner calli and cell suspension cultures
}

\author{
D. Sachithri P. Munasinghe. ${ }^{1}$, Seneviratnege Somaratne ${ }^{1}$, Shyama R. Weerakoon ${ }^{*}$, Chandani Ranasinghe ${ }^{2}$
}

\begin{abstract}
Aloeswood or Agarwood has long been perfumery commodity traded between Mediterranean Region and Southeast Asia since ancient times. Oil or chips are obtained by destructive harvesting of several Thymeleaceous genera includes Aquilaria and Gonystylus and are expensive and highly demanded ingredients in the global market. The recent recovery of Gyrinops walla as a potential producer of market-quality agarwood in mature damaged woods and branches, the intense illicit felling and exportation $G$. walla leading to the verge of extinction from Sri Lankan flora. The sustainable utilization of $G$. walla undoubtedly enhances the foreign exchange of the country and the non-destructive utilization $G$. walla through biotechnology is the only option available for sustainable exploitation and conservation of the vulnerable $G$. walla species. An electro-elicitation apparatuses were designed and built to stimulate calli and cell suspensions. The elicited and calli and cell suspensions were harvested at different time periods to extract sesquiterpenes. Current intensities of $10 \mathrm{~mA}$ and $50 \mathrm{~mA}$, and $0.1 \mathrm{~mA}$ were the optimum values for the induction of sesquiterpenes; $\gamma$-selinene, $\beta$-caryophyllene, $\alpha$-cadinol and $\alpha$-guaiene, production in both calli and cell suspension after 8 weeks and 6 hours, respectively. The findings of the study led to conclude the possibility of induction of production of sesquiterpenes through electro-elicitation of $G$. walla calli and cell suspension in an in vitro system for sustainable utilization and conservation endeavours.
\end{abstract}

Keywords: Sesquiterpenes, sustainability, Gyrinops walla, in vitro production, electro-elicitation

${ }^{1}$ Department of Botany, The Open University of Sri Lanka, Nawala, Sri Lanka.

${ }^{2}$ Department of Chemistry, The Open University of Sri Lanka, Nawala, Sri Lanka.

*Corresponding author: shyamaweerakoon@gmail. com

DOI: $10.2478 /$ ebtj-2021-0011

(๑) 2021 Authors. This work was licensed under the Creative Commons Attribution-NonCommercialNoDerivs 4.0 License.

\section{Introduction}

Gyrinops is a member of the Thymelaeaceae family and belongs to the subfamily Thymelaeoideae and tribe Synandrodaphneae (1). G. walla is particularly distributed in forest areas within the lower elevations (below $1525 \mathrm{~m}$ from the ocean level) of Sri Lanka, restricted to Western, Sabaragamuwa and Southern Provinces (2). Gyrinops is moreover classified as agarwood-producing species, similarly to Aquilaria and they are the most important species in family Thymelaeceae for producing agarwood (3). At the present, only three species are known for agarwood producers: G. ledermannii (4), G. versteegii (3), and G. walla (5).

Agarwood is a dark resinous substance, extremely appreciated in luxury perfumery and fragrance industries. Fragrant compounds of agarwood are known to be sesquiterpenoids and chromone derivatives, which are the reasons of agarwood's characteristic odour (6). Agarwood oils vary in their composition; some oils contain an immense amount of sesquiterpene compounds while some contains principally benzyl acetone (7). Further, the usage of agarwood is profoundly in traditional East Asian medicine to alleviate pain, cure for vomiting by warming the stomach, and to remedy for asthma (Anon, 1995 cited in 8). Top quality Agarwood powder is employed in Chinese medicine (9) and is additionally utilized in the preparation of pharmaceutical tinctures (10).

It is hypothesized that agarwood production is related to a physiological disturbance, like wounding (tree falling as a result of epiphyte load or a storm) or insect attack (11), which is followed by colonization of the exposed tissues by microbes. As a response to the 
strain of wounding and microbial infection, agarwood producing species of Thymelaeaceae may activate its plant defense system triggering the assembly of a resin, which is high in volatile organic compounds that aid in suppressing and localizing the infected area which helps plant to resist or delay the infection by tylosis (12). It has been reported that in natural forest, ca. $7 \%$ of the trees are infected by fungus, Phaeoacremonium parasitica which belongs to Ascomycetous mold (13). This adematiaceous (dark-walled) fungus is one among the known fungi reported to be related to Agarwood formation.

During 2012, large scale illicit felling and exporting of $G$. walla chips have been reported due to the popularity "Walla patta" gained, with the discovery of its similarity between the agarwood in commerce. Since then, being a tree producing quality agarwood. Subsequently, prohibition of exporting was set forth in 2012 (14) and categorized as a vulnerable species, according to IUCN Red List Categories (15). Conventionally, destructive harvesting is employed to acquire agarwood chips and oil present in trees or after inducing agarwood formation artificially. However, destructive harvesting is not suitable in obtaining agarwood from $G$. walla because it's the sole representative species for agarwood in Sri Lanka and therefore the population is declining at an unpredicted pace due to illicit trading. Thus, it's necessary to conserve this valuable species using biotechnological methods to facilitate the formation of agarwood constituents ex situ by elicitation of callus/cell cultures.

Callus and cell suspension culture systems are used nowadays for large-scale production of plant cells from which secondary metabolites are extracted. The major advantage of the cell culture is that synthesis of bioactive secondary metabolites is possible running in controlled environment, independently from climate and soil conditions (16). Cell cultures assist in two major ways in production of plant secondary metabolites by yielding defined standard phytochemicals in large volumes and eliminating the presence of interfering compounds that occur in the field-grown plants (17). The first large scale application of large-scale cultivation of plant cells was conducted for cell culture of Lithospermum erythrorhizo to produce shikonin, carried out in stirred tank reactors of 200 liter and 750 liter capacities (18). A few medicinally important alkaloids, anticancer drugs, recombinant proteins and food additives are produced in various cultures of plant cell and tissues in bioreactors. Developments made in the callus and cell culture has made the possibility of producing wide range of medicinally important compounds such as alkaloids, terpenoids, steroids, saponins, phenolics, flavonoids and amino acids (19).

Aquilaria species are a unique group of agarwood producing tropical trees which take many years to grow and mature. Due to the long time to reach maturity, studies based on fresh plants (ex vitro) have been scarce. The first attempt to establish plant cell culture techniques for Aquilaria species was reported in 2005 by Qi et al. (20) successfully established cell suspensions from root tissue obtained from in vitro germinated plantlets of $A$. sinensis, while Okudera and Ito (21) established cell sus- pension cultures using leaf tissue from seedlings of A. crassna, which had been germinated and grown in a greenhouses. To date, no studies have been reported on the establishment of cell cultures and/or production of secondary metabolites in Gyrinops walla. The present study reports the feasibility of in vitro producing sesquiterpenes using electro-elicitation method.

\section{Materials and Methods \\ Construction of Electro-elicitation apparatus for $G$. walla callus and cell suspension}

An apparatus was designed for stimulation of callus (Figure 1 a) and cell suspension (Figure $1 \mathrm{~d}$ ) according to Cogalniceanu et al. (22) with some modifications. An aluminium wire (0.4 $\mathrm{mm}$ in diameter) and an aluminium disk of $0.3 \mathrm{~mm}$ in thickness were served as electrodes to electro-elicitate calli. The aluminium wire was inserted through a hole made in the lid of the Petri plate with a screw attached to the wire to adjust the distance between the callus and the wire electrode (Figure 1 b). The aluminium disk was prepared by cutting into a circle with a blade, fitting to the bottom part of the Petri plate (Figure $1 \mathrm{c})$. An aluminium wire was soldered to the aluminium disk and the wire was taken out through a hole made in the side of the Petri plate closer to the bottom of the Petri plate. The holes were air sealed properly to prevent contaminations. The apparatus was filled with $15 \mathrm{ml}$ of MSM supplemented with $30.0 \mathrm{~g} / \mathrm{l}$ sucrose, $100.0 \mathrm{mg} / \mathrm{l}$ myo-inositol, $10 \mathrm{~g} / \mathrm{l}$ agar, $0.5 \mathrm{mg} / \mathrm{l} \mathrm{BAP}$ and $2.5 \mathrm{mg} / \mathrm{l} \mathrm{NAA}$ on the top of the aluminium disk and the entire apparatus with MSM was autoclaved accordingly.

The two electrodes were made using $15 \mathrm{~cm}$ of PTFE - insulated stainless steel wire (uninsulated diameter $-0.25 \mathrm{~mm}$ ) for $G$. walla cell suspension by removing the insulating case at ca. $5 \mathrm{~cm}$ at the ends of wires (Figure $1 \mathrm{~d}$ ). Both electrodes were inserted in to $150 \mathrm{ml}$ Erlenmeyer flask, 2 - $20 \mathrm{~mm}$ distance from each electrode in the medium, containing $15 \mathrm{ml}$ of MSM supplemented with $30.0 \mathrm{~g} / \mathrm{l}$ sucrose, $100.0 \mathrm{mg} / \mathrm{l}$ myo-inositol, $0.5 \mathrm{mg} / \mathrm{l} \mathrm{BAP}$ and $2.5 \mathrm{mg} / \mathrm{l} \mathrm{NAA}$. The wires were bent over the rim of the flask and top was covered with an aluminium foil, before sterilized by autoclaving.

\section{Exposing callus to electro-elicitation}

Callus and cell suspensions were established according to $\mathrm{Mu}-$ nasinghe et al (23). Five Petri dishes, electrically coupled in series, were set up for varying electric current density. The control consisted of a set of five Petri dishes kept in the same conditions (Figure 2). In preliminary tests, it was shown that there were significant differences hardly any between the morphogenetic response of the control samples with electrodes inserted into the callus, but not connected to the current generator, and the samples without electrodes (22). Therefore, callus without no electrodes were used as the control.

A portion of $2 \mathrm{~g}$ in weight calli were transferred to the apparatus aseptically and allowed to develop in the apparatus for two weeks. Two weeks later, four electric current units were tested $0.1 \mathrm{~mA}, 1 \mathrm{~mA}, 10 \mathrm{~mA}$ and $50 \mathrm{~mA}$ at $50 \mathrm{~Hz}$ for $5 \mathrm{~min}$ supplied from a DC power supplier. The signals were applied 
(a)
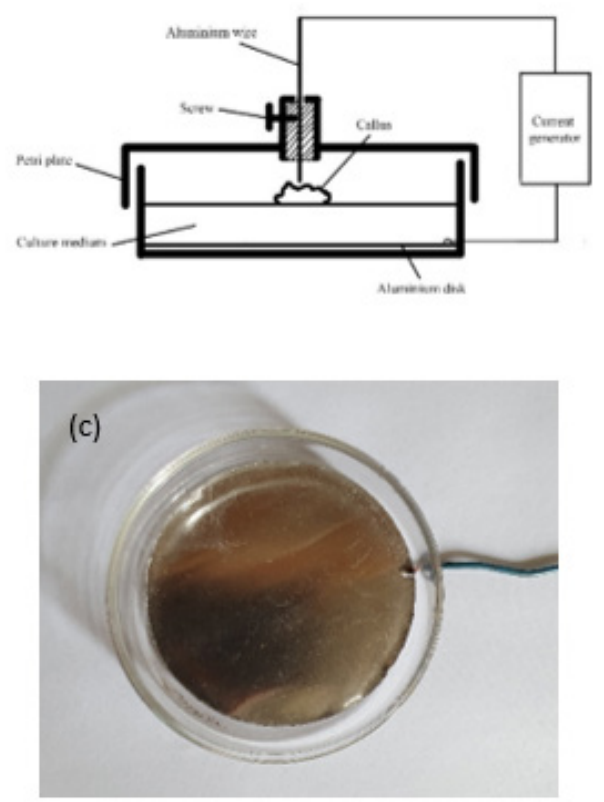
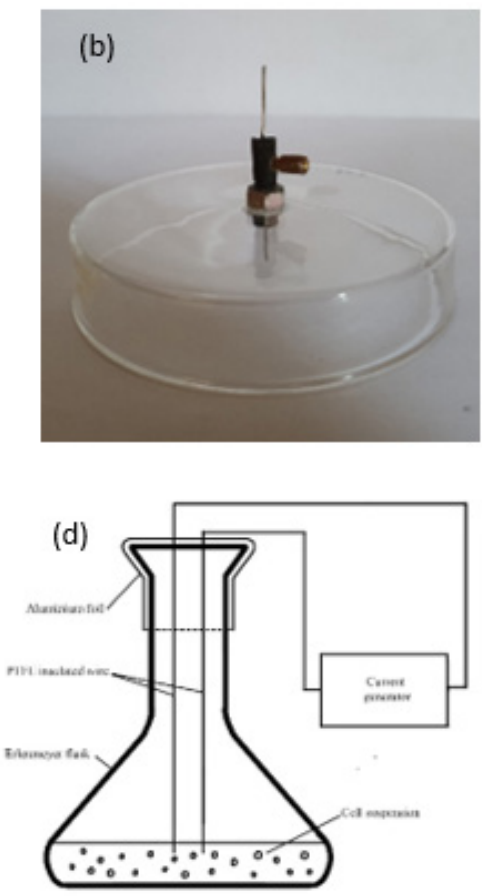

Figure 1: Experiment set up for the electrostimulation for G. walla callus and cell suspension(a) diagram of the electro-elicitation apparatus for calli, (b) attached screw to adjust the distance between the callus and the wire electrode, (c) bottom part with aluminium disk and (d) diagram of electro-elicitation apparatus for cell suspension.

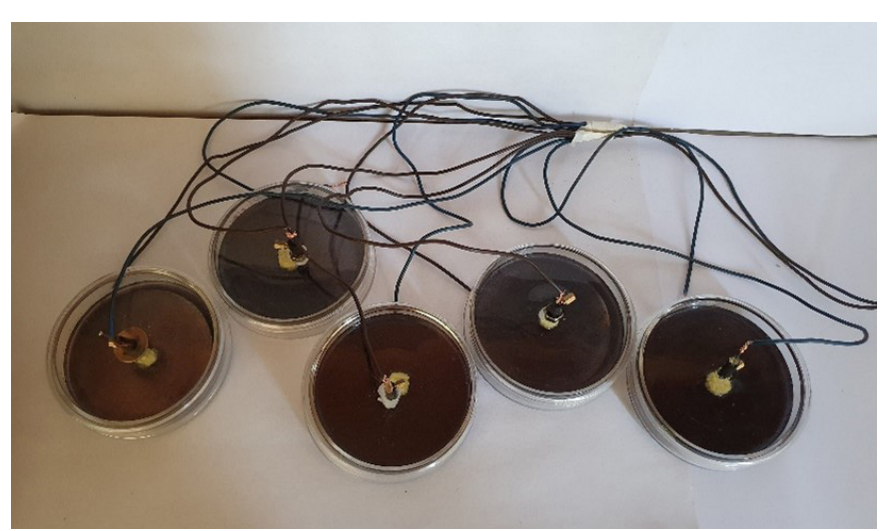

Figure 2. Electro-elicitation apparatus for calli which are electrically coupled in series.

separately for all intensities tested, coupling the sets of five Petri dishes in a serial circuit (Figure 2). The intensity level through each series of five calli was established with an appropriate electrical resistance. The calli were incubated at $25^{\circ} \mathrm{C}$ in the dark for 2 to 16 weeks and were harvested every 2 weeks for analysis by GC-MS with three times replication. Cell viability was assessed using the 2, 3, 5, - triphenyltetrazolium chloride (TTC) reduction method during the incubation period.

\section{Electro-elicitation of cell suspension}

Five Erlenmeyer flasks were electrically coupled in series (Figure 3) and set up for each value of the electric current intensity as mentioned in electro-elicitation of calli. The same set-up of cell suspension without supplying electric current served as the control. Three weeks old cell suspensions (ca. $1 \mathrm{~g}$ ) were subjected for electro-stimulation. The cell suspension was transferred to the apparatus aseptically and four current intensities were tested $50 \mu \mathrm{A}, 100 \mu \mathrm{A}$ and $0.1 \mathrm{~mA}$, at $50 \mathrm{~Hz}$ for $5 \mathrm{~min}$. The signals were applied separately for all intensity values tested, coupling the sets of five flasks connected in a serial circuit. Cells were harvested on different time period $(0 \mathrm{~h}, 0.5 \mathrm{~h}, 2 \mathrm{~h}, 4 \mathrm{~h}, 6 \mathrm{~h}$, $12 \mathrm{~h}, 24 \mathrm{~h}, 72 \mathrm{~h}$ ) after treatment with electric current.Cell viability was assessed using the 2, 3, 5, - triphenyltetrazolium chloride (TTC) reduction method during the incubation period.

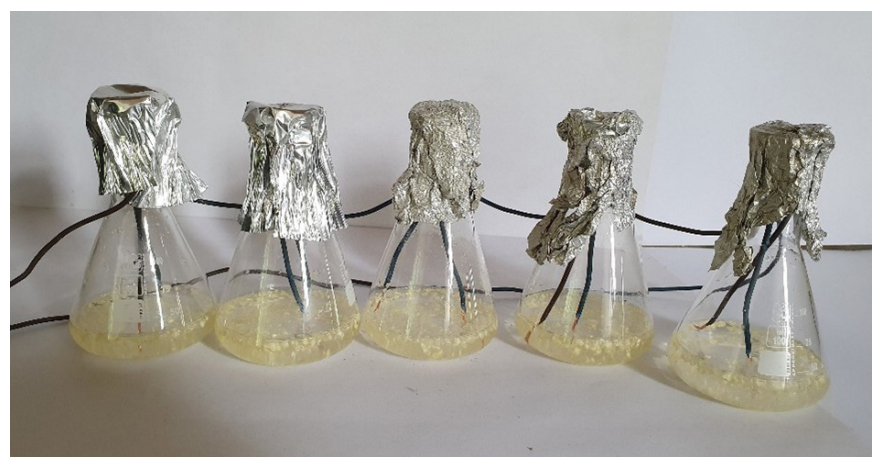

Figure 3. Electro-elicitation apparatus for cell suspension which are electrically coupled in series. 
Extraction of agarwood type constituents of elicited calli and cell suspensions

Extraction of secondary metabolites in elicited calli and cell suspensions was carried out according to Jain et al. (24) modified with sonification. Harvested callus and cell suspension were dried in $50 \mathrm{OC}$ in the oven for overnight to a constant weight. The dried calli and cell suspensions were subsequently ground to a fine powder in liquid nitrogen, using a mortar and pestle. Approximately $5 \mathrm{~g}$ of the fine powder was transferred to $50 \mathrm{ml}$ Erlenmeyer flask containing $10 \mathrm{ml}$ of $100 \%$ hexane and incubated at room temperature at 150rpm shaking incubator for 3 days. Subsequently, the sample was sonicated using an ultrasonic water bath for 60 minutes. The sample was centrifuged in $2500 \mathrm{G}$ for 10 minutes and the supernatant was transferred to a new vessel. The resultant supernatant was evaporated in room temperature to remove excess solvent and stored in $4 \mathrm{oC}$ until chemicals analysis.

\section{Chemicals analysis}

Chemical analyses were performed at the Herbal Division, Industrial Technology Institute (ITI), Malabe. Thin Layer Chromatography (TLC) was performed using pre-coated Silica gel 60 GF254 plates and approximately $6 \mu$ of each sample was spotted on the TLC plate, air-dried and placed in the chromatographic chamber previously saturated with the solvent system (25\% ethyl acetate and 75\% hexane). Developed TLC plates were observed under UV $366 \mathrm{~nm}, 245 \mathrm{~nm}$ and after spraying with vanillin spray reagent followed by heating at 105 ${ }^{\circ} \mathrm{C}$ for 3-5 minutes.

The GC-MS was run with a Thermo Scientific Trace 1300 (USA) fused with silica HP-5MS capillary column (30 $\mathrm{m} \times 0.25$ $\mathrm{mm} \times 0.25 \mu \mathrm{m}$ ). The oven temperature was programmed initially $50 \mathrm{oC}$ for 2 minutes following $200 \mathrm{oC}$ for 1 minute with a rate of $40 \mathrm{oC} / \mathrm{min}$ and at $320 \mathrm{oC}$ for 15 minutes with a rate of $3 \mathrm{oC} /$ $\mathrm{min}$. The gas chromatogram was coupled to an ISQDD mass selective detector (Thermo Scientific, USA). The MS operating parameters were; ionization voltage, $70 \mathrm{eV}$ and ion source temperature, $250 \mathrm{oC}$. High-purity (over purity $99.99 \%$ ) helium was used as the carrier gas. Identification of compounds was based on comparisons of their mass spectra with those recorded in the National Institute of Standards and Technology database (NIST, Version 2.09, MD, USA).

\section{Data analysis}

The descriptive statistics such as mean and Standard Deviation (SD) were calculated for the data obtained. Further, the relationship between the incubation time and area percentages of sesquiterpenes were graphically presented along with the trends. The inferential statistics such ANOVA and Tukey's Honest Test were performed to compare the means. All statistical analyses were performed using SAS (Ver. 9) (2008).

\section{Results}

Effectiveness of the production of sesquiterpenes in calli and cell suspensions subjected to different stress stimuli were ini- tially assessed via visual observation on callus/cell suspension colour, sensory evaluation by sniffing before harvesting and TLC profiles observed under UV $366 \mathrm{~nm}$, which had similar profiles to that of hexane extracts $G$. walla wood after harvesting. The results were used to determine the stress conditions to be further analysed via GC-MS to assess the amount of sesquiterpenes. Considering the relative abundance of sesquiterpenes detected via GC-MS, relative percentage of four (04) prominent sesquiterpenes; namely $\gamma$-selinene, $\beta$-caryophyllene, $\alpha$-cadinol and $\alpha$-guaiene were used to assess the productivity of each elicitation method and their conditions. Silane and siloxane compounds were neglected in obtained chromatograms.

\section{Electro-elicitation of $G$. walla callus and cell suspen- sion}

Immediately after the electro-elicitation, the calli in all the experimental conditions turned to pale brown to brown in colour during the elicitation period and spots were detected only in 10 $\mathrm{mA}$ and $50 \mathrm{~mA}$ starting from 8 weeks and 6 weeks, respectively. TLC spots were hardly noticeable with 2 to 3 pale blue spots with Rf values of $0.32,0.56$, and 0.93 (Figure 3 a). Cell viability with TTC reduction test indicated that elicited calli were viable only upto 8th or 10th week during the incubation period.

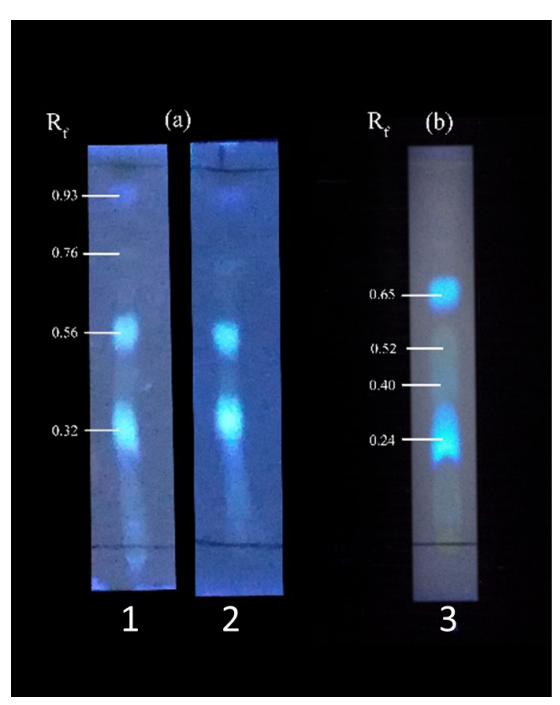

Figure 4. TLC profiles of electro-elicited G. walla(a) calli1) 10 $\mathrm{mA}$, 2) $50 \mathrm{~mA}$ on 8 th week and (b) cell suspension3) $0.1 \mathrm{~mA}$ on 6th hour.

Higher area percentages of sesquiterpenes were observed on 8thand 10thweek of incubation for both current intensities and area percentage of $\beta$-caryophyllene and $\alpha$-cardinal were observed higher compared to that of $\gamma$-selinene and $\alpha$ guanine under the intensity of $10 \mathrm{~mA}$ (Figure $4 \mathrm{a}$ ). However, higher area percentage of $\beta$-caryophyllene and $\gamma$-selinene were observed while calli were treated with $50 \mathrm{~mA}$. Considering the effectiveness of the electro-elicitation on $G$. walla calli, both current intensities had similar effect on the area percentage of the sesquiterpenes (Table 1). 


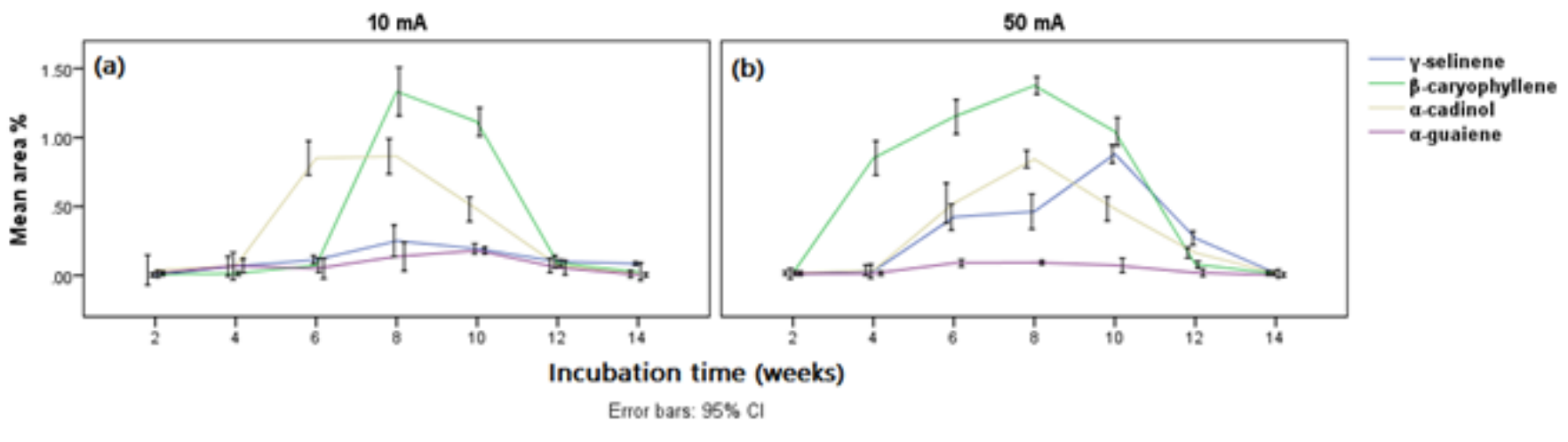

Figure 5. Mean area percentages of sesquiterpenes produced in G. walla calli under electric currents of (a) $10 \mathrm{~mA}$ and (b) $50 \mathrm{~mA}$.

Table 1. Effect of electro-elicitation on G. walla calli

\begin{tabular}{|c|c|c|c|c|c|c|}
\hline Intensity & Incubation period & \multicolumn{5}{|c|}{ Area percentage of } \\
\hline Control & (weeks) & $\gamma$-selinne & $\beta$-caryophyllene & a-cardinol & $\alpha$-guaiene \\
\hline 10 & 2 & $0.01(0.005)^{\mathrm{e}}$ & $0.01(0.01)^{\mathrm{e}}$ & $0.04(0.005)^{\mathrm{d}}$ & $0.01(0.005)^{\mathrm{g}}$ \\
\hline 10 & 4 & $0.06(0.04)^{\mathrm{ed}}$ & $0.01(0.005)^{\mathrm{e}}$ & $0.06(0.02)^{\mathrm{d}}$ & $0.07(0.02)^{\mathrm{de}}$ \\
\hline 10 & 6 & $0.11(0.01)^{\mathrm{ed}}$ & $0.07(0.02)^{\mathrm{e}}$ & $0.85(0.05)^{\mathrm{b}}$ & $0.05(0.03)^{\mathrm{ef}}$ \\
\hline 10 & 8 & $0.25(0.04)^{\mathrm{bcde}}$ & $1.33(0.07)^{\mathrm{a}}$ & $0.86(0.05)^{\mathrm{a}}$ & $0.13(0.04)^{\mathrm{b}}$ \\
\hline 10 & 10 & $0.19(0.01)^{\mathrm{ed}}$ & $1.11(0.04)^{\mathrm{ab}}$ & $0.48(0.03)^{\mathrm{bc}}$ & $0.18(0.01)^{\mathrm{a}}$ \\
\hline 10 & 12 & $0.10(0.01)^{\mathrm{ed}}$ & $0.09(0.01)^{\mathrm{e}}$ & $0.07(0.02)^{\mathrm{d}}$ & $0.05(0.02)^{\mathrm{de}}$ \\
\hline 10 & 14 & $0.08(0.005)^{\mathrm{ed}}$ & $0.02(0.002)^{\mathrm{e}}$ & $0.01(0.004)^{\mathrm{d}}$ & $0.01(0.006)^{\mathrm{g}}$ \\
\hline 50 & 2 & $0.01(0.003)^{\mathrm{e}}$ & $0.01(0.001)^{\mathrm{e}}$ & $0.01(0.005)^{\mathrm{d}}$ & $0.01(0.005)^{\mathrm{g}}$ \\
\hline 50 & 4 & $0.03(0.02)^{\mathrm{ed}}$ & $0.85(0.05)^{\mathrm{d}}$ & $0.03(0.01)^{\mathrm{d}}$ & $0.01(0.005)^{\mathrm{g}}$ \\
\hline 50 & 6 & $0.42(0.03)^{\mathrm{cb}}$ & $1.15(0.05)^{\mathrm{c}}$ & $0.52(0.05)^{\mathrm{b}}$ & $0.09(0.01)^{\mathrm{cd}}$ \\
\hline 50 & 8 & $0.46(0.05)^{\mathrm{b}}$ & $1.37(0.02)^{\mathrm{bc}}$ & $0.84(0.02)^{\mathrm{a}}$ & $0.09(0.005)^{\mathrm{bc}}$ \\
\hline 50 & 10 & $0.88(0.02)^{\mathrm{bcd}}$ & $1.04(0.04)^{\mathrm{cd}}$ & $0.48(0.03)^{\mathrm{b}}$ & $0.07(0.02)^{\mathrm{de}}$ \\
\hline 50 & 12 & $0.27(0.02)^{\mathrm{a}}$ & $0.08(0.02)^{\mathrm{e}}$ & $0.16(0.01)^{\mathrm{cd}}$ & $0.02(0.01)^{\mathrm{gf}}$ \\
\hline 50 & 14 & $0.01(0.005)^{\mathrm{e}}$ & $0.01(0.01)^{\mathrm{e}}$ & $0.01(0.004)^{\mathrm{d}}$ & $0.01(0.006)^{\mathrm{g}}$ \\
\hline
\end{tabular}

The mean values are followed standard deviation within parenthesis. The same letter along the columns indicates no statistically significant difference at $\mathrm{p} \leq 0.05$

Conversely, negligible or no effect was observed for the $G$. walla cell suspension under electro-elicitation except for 0.1 $\mathrm{mA}$, in which spots were observed after 6 hours of incubation period. However, aroma was not detected for calli and cell suspension under electro-elicitation during the elicitation period.

TLC profiles of $G$. walla cell suspension under electro-elicitation indicated similar spots pattern as in electro-elicitation of callli with pale light and pale blue in colour (Figure $5 \mathrm{~b}$ ).Cell viability with TTC reduction test indicated that elicited cell suspensions were viable only up to 6th or 12th hour during the incubation period and majority the cell suspensions were not viable in 72 nd hour.

Comparatively, area percentages of the sesquiterpenes obtained from the cell suspension of $G$. walla under the electro-elicitation indicated distinct results to that of electro-elic- itation of $G$. walla calli. Only three types of sesquiterpenes, namely $\beta$-caryophyllene, $\gamma$-selinene and $\alpha$-guanine in lower amounts were detected (Figure 6). Characteristically, higher area percentage of a-guanine $(0.16 \%)$ was produced in electro-elicited cell suspension while the area percentage of $\beta$-caryophyllene and $\gamma$-selinene were lower (Table 2).

Under the treatment of electro-elicitation of calli indicated four distinct trends of sesquiterpenes (Figure 7 a). Early production of $\beta$-caryophyllene was observed and two distinct behaviours were observed, while $G$. walla cell suspension were electro-elicited, consisted of a-guaiene (pattern 1) and, $\beta$-caryophyllene and $\gamma$-selinene (pattern 2) (Figure 7 b). In addition, the area percentage of $\alpha$-guaiene was higher than that of $\beta$-caryophyllene and $\gamma$-selinene. 


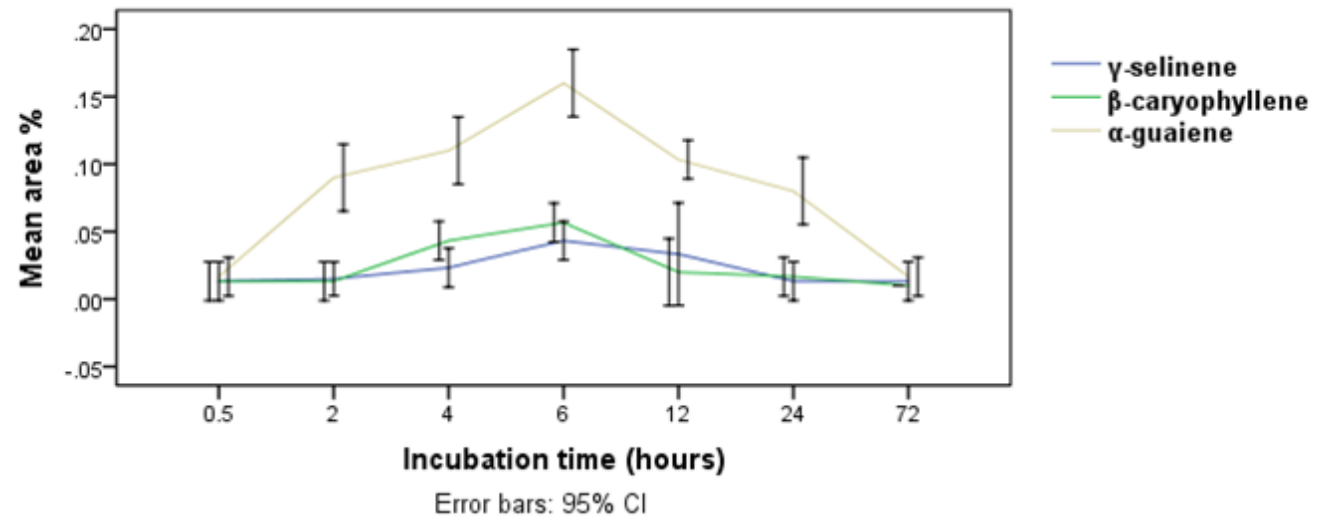

Figure 6. Mean area percentages of sesquiterpenes produced in $G$. walla cell suspension under electric current $0.1 \mathrm{~mA}$

Table 2. Effect of electro-elicitation $G$. walla cell suspension

\begin{tabular}{|c|c|c|c|c|}
\hline \multirow{2}{*}{ Intensity } & Incubation period & \multicolumn{3}{|c|}{ Area percentage of } \\
\cline { 3 - 5 } & 0 & $\gamma$-selinene & $\beta$-caryophyllene & $\alpha$-guaiene \\
\hline Control & 0.5 & $0.01(0.005)^{\mathrm{d}}$ & $0.01(0.005)^{\mathrm{b}}$ & $0.01(0.005)^{\mathrm{d}}$ \\
\hline 0.1 & 2 & $0.01(0.003)^{\mathrm{c}}$ & $0.01(0.005)^{\mathrm{b}}$ & $0.02(0.001)^{\mathrm{c}}$ \\
\hline 0.1 & 4 & $0.01(0.005)^{\mathrm{c}}$ & $0.01(0.005)^{\mathrm{b}}$ & $0.09(0.01)^{\mathrm{b}}$ \\
\hline 0.1 & 6 & $0.02(0.005)^{\mathrm{bc}}$ & $0.04(0.005)^{\mathrm{b}}$ & $0.11(0.01)^{\mathrm{b}}$ \\
\hline 0.1 & 12 & $0.04(0.005)^{\mathrm{ab}}$ & $0.05(0.001)^{\mathrm{a}}$ & $0.16(0.01)^{\mathrm{a}}$ \\
\hline 0.1 & 24 & $0.03(0.01)^{\mathrm{a}}$ & $0.02(0.01)^{\mathrm{b}}$ & $0.10(0.003)^{\mathrm{b}}$ \\
\hline 0.1 & 72 & $0.01(0.005)^{\mathrm{d}}$ & $0.01(0.005)^{\mathrm{b}}$ & $0.08(0.01)^{\mathrm{b}}$ \\
\hline 0.1 & $0.01(0.005)^{\mathrm{d}}$ & $0.01(0.005)^{\mathrm{b}}$ & $0.01(0.005)^{\mathrm{d}}$ \\
\hline
\end{tabular}

The mean values are followed standard deviation within parenthesis. The same letter along the columns indicates no statistically significant difference at $\mathrm{p} \leq 0.05$

\section{Discussion}

During the production of sesquiterpenes in artificially elicited calli and cell suspension cultures of $G$. walla, the peaks of different sesquiterpenes were appeared and rapidly attenuated, and the aroma simultaneously faded away in certain elicitation conditions after 8 weeks and 6 hours, respectively. This implies that different pathways of sesquiterpenes of highly volatile to less volatile compounds are involved and the volatile compounds might be escaped from the system immediately. Further, during the elicitation, interaction among the sesquiterpenes and the feedback mechanisms involved in inhibition and activation of enzyme systems through gene expression, could be one of the plausible explanations of transient appearance of volatile compounds. Various mechanisms have been put forwarded to explain these observations such as degradation by endogenous enzymes (21) and diffusion of the aromatic compounds into the air which supports the findings of the present study. In addition, results of the study suggested that viability of the calli and cell suspension are essential in production of sesquiterpenes. However, in the production of chromone compounds, cell viability does not play a major role. Okudera and Ito (21) are in the opinion that chromone derivatives are produced by the degradation of cell wall constituents by endogenous enzymes during the process of cell death and sesquiterpenes are compounds whose biosynthesis is induced by signal transducers which happens when cells are viable. This finding supports the observations of the present study regarding appearance of sesquiterpenes when calli/cell suspension are viable. Moreover, findings of the present study indicates that maximum incubation period for $G$. walla calli and cell suspension are 8 or 10 weeks and 12 hours, respectively. In the present study, sesquiterpenes- $\alpha$-cadinol, $\beta$-caryophyllene, $\alpha$-guaiene and $\gamma$-selinene which are identical to that of the wood, were obtained from the three elicitation methods. All these findings imply that potential of electro-elicitating calli and cell suspensions of $G$. walla to induce synthesis of sesquiterpenes.

The constructed electro-elicitation apparatus were capable in electro-stimulation of calli and cell suspensions of $G$. walla by producing sesquiterpenes. However, extensive browning was occurred in calli which would indicate a burning of cells due to heat generated during the electro-elicitation other than necrosis of cells in the cultures. However, the occurrence of 

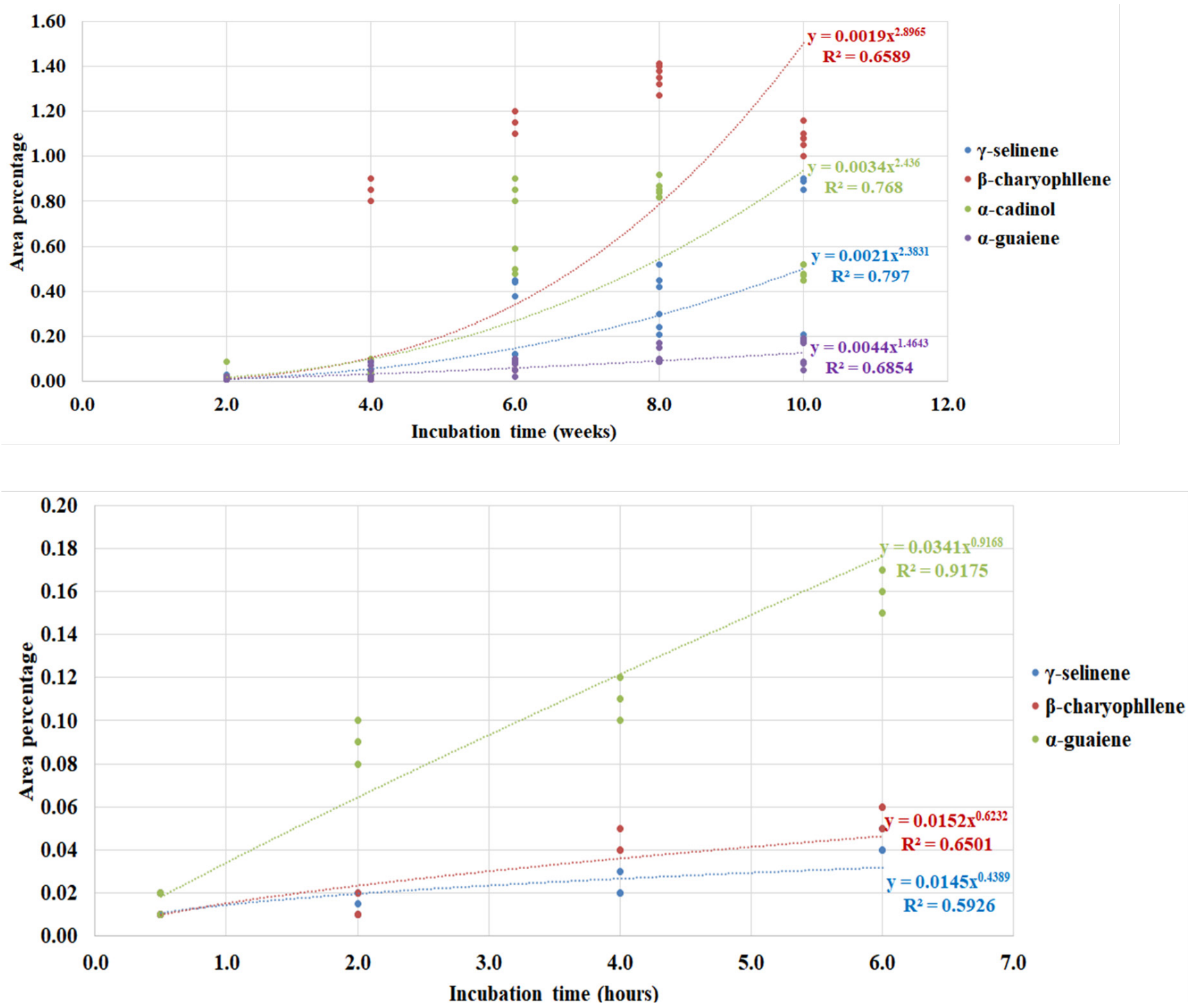

Figure 7. Trends of area percentages of biologically elicited (a) G.walla calli and (b) cell suspension. Note: the graphs included the data upto maximum area percentage of sesquiterpenes

type of sesquiterpenes were differed in higher current intensity (50 $\mathrm{mA}$ ) shifting $\alpha$-cardinal to $\gamma$-selinene. Even though, the exact reason for having higher area percentage of $\gamma$-selinene under higher current intensity is not clear, it can be hypothzised that genes related $\gamma$-selinene initiate to express in the critical point where more disruptive damages caused to the cells which in turn induce traumatic stimuli.

In contrast, only three sesquiterpenes were detected in cell suspension of G. wallla. The suppression of production of a-cardinol could be attributed due to the factors such as nature of the culture and heat generated during electro-elicitation. Occurrence of three sesquiterpenes also indicates that comparatively, this method is less effective. In electro-elicitation of $G$. walla cell suspension, the area percentage of a-guanine was higher. As the sensitivity of cell suspension is higher to any physical stress condition, $\alpha$-guanine could be acting as a wound healing agent. Careful observations of Figure 7 revealed that in calli of all four sesquiterpenes were occurred in four differ- ent times while in cell suspension, two were occurred in one time and the other was occurred in separately, which implies that factors such as, ionic compositions of the culture medium, electric resistance of agar in the medium, relationship between chemical polarity and electric conductivity of the solvents and surface angles of the calli need to be considered to optimise the elicitation to get all the sesquiterpenes concurrently.

Although, the exact mechanism behind electro-elicitation in obtaining secondary metabolites is not clearly understood, several theoretical concepts have been presented by Cogalniceanu et al. (22). One of the hypotheses explains that plant cells subjected to an external electric current manifest a modulation of their own electric patterns. Whatever type and level of external electric field is used in stimulative experiments, an interference between exogenous and endogenous electric fields occurs with consequences on the simultaneous processes. Another hypothesis of them states that being callus and cell suspension undifferentiated, the flow of electrical signals between cells is 
not well characterized which allows a physical factor to govern specific pathway of differentiation and morphogenesis.

Similarly, usage of electric current was also conducted for biosynthesis of (+)-Pisatin using root cultures of Trifolium pretense, Cicer arietinum, Trigonella foenum-graecum, Pisum sativum, Sophora japonica, Sorghum bicolor and Arabidopsis thaliana in which indicated the effectiveness of electro-elicitation on root cultures (25). Although, the scientific literature on electric current on plant calli and cell suspension for the production of secondary metabolites are scarce, the effect of pulsed electric field (PEF) on growth and secondary metabolism of certain plant species have been conducted. Such examples include the production of anthocyanins and phenolic acids synthesis using suspension culture of Vitis vinifera (26) and intracellular accumulation of taxuyunnanine $\mathrm{C}(\mathrm{Tc})$ using suspension cultures of Taxus chinensis (27). However, stimulation of shoot regeneration in tobacco callus indicates the possibility of eliciting calli cultures under electric current where the degree of stimulation is correlated with the current intensity (Rathore and Goldsworthy, 1985). As far as family Thymelaeaceae is concerned, there is a lacuna of published records on electro-elicitation for calli and cell suspension.

\section{Conclusion}

The physical elicitation of calli and cell suspension of G. walla proved the feasibility of production of four sesquiterpenes ( $\gamma$-selinene, $\alpha$-guaiene, $\beta$-caryophyllene and $\alpha$-cadinol) under laboratory condition. Studies are required to affirm the feasibility of mass production of agarwood resinous substances using pilot-scale systems such as bioreactors with hairy root culture.

\section{Disclosure statement}

The authors declare that there is no conflict of interest.

\section{Funding}

This study was funded by OUSL Competitive Research Grant - 2016 (OU201601).

\section{Acknowledgement}

The technical assistance given by the staff of the Industrial Technology Institute, Malabe, Botany and Chemistry Research Laboratories of the Open University of Sri Lanka, Nugegoda is highly acknowledged.

\section{References}

1. Herber BE, Metcalfe C R, Chalk. Anatomy of the dicotyledons. Systematic anatomy of the leaf and stem, with a brief history of the subject 1988;(Ed. 2).Volume I.

2. Gunatilleke IAUN, Gunatilleke CVS, Dilhan MAAB. Plant biogeography and conservation of the southwestern hill forests of Sri Lanka. Raf. Bul. Zoo 2005;12(1): 9-22.

3. Compton JGS Zich FA. Gyrinops ledermannii (Thymalaeaceae), being an agarwood producing species prompts call for further examination of taxonomic implications in the generic delimitation between Aquilaria and Gyrinops.
Flora Malesiana bulletin 2002;13(1), 61-66.

4. Takeuch W, Golma M. The present status of Ledermann's April River localities in Papua New Guinea. SIDA, Contributions to Botany 2002;55-70.

5. Subasinghe S M C UP, Hettiarachchi DS, Rathnamalala E. Agarwood-type resin from Gyrinops walla Gaertn: a new discovery 2012.

6. Takemoto H, Ito M, Shiraki T, Yagura T, Honda G. Sedative effects of vapor inhalation of agarwood oil and spikenard extract and identification of their active components. Journal of natural medicines 2008;62(1), 41-46.

7. Yang JS, Wanf YL, Su YL, He DH, Zheng QT, Yang J. Studies on the chemical constituents of Aquilaria sinensis (Luor) Gilg. Elucidation of the structure of the isobaimuxinol and isolation and identification of the constituents of lower boiling fraction of the volatile oil. Yao Xue Xue Bao 1989;24(4): 264-268.

8. Akter A, Neelim A. Agarwood Plantation at BRAC Tea Estate: Introduction, Environmental Factors and Financial Analysis. BRAC Research Report, Research and Evaluation Division BRAC Centre, 75 Mohakhali, Dhaka 1212, Bangladesh 2008

9. Yaacob S. Agarwood: Trade and CITES Implementation in Malaysia. Unpublished report prepared for TRAFFIC Southeast Asia, Malaysia 1999.

10. Van Beek H H, Phillips D. Agarwood: Trade and CITES implementation in Southeast Asia, Unpublished report prepared for TRAFFIC Southeast Asia, Malaysia 1999.

11. Ng LT, Chang YS, Kadir AA. A review on agar (gaharu) producing Aquilaria species. Journal of Tropical Forest Products 1997;2 (2): 272-285.

12. Nobuchi T,Siripatanadilok S. Preliminary observation of Aquilaria crassna wood associate with the formation of aloeswood. Bulletin of the Kyoto University Forests (Japan) 1991;63, 226-235.

13. Crous P W, Gams W, Wingfield MJ, Van Wyk, P S. Phaeoacremonium gen. nov. associated with wilt and decline diseases of woody hosts and human infections. Mycologia 1996;88(5), 786-796.

14. Dharmadasa RM, Siriwardana A, Samarasinghe K, Adhihetty P. Standardization of Gyrinops Walla Gaertn. (Thymalaeaceae): Newly Discovered, Fragrant Industrial Potential, Endemic Plant from Sri Lanka. W. Jo. Agri. Res 2013;1(6):101-103.

15. MOE. The Notational Red List 2012 of Sri Lanka. Conservation status of the Fauna and Flora. Ministry of Environment, Colombo, Sri Lanka. 2012; Viii :476.

16. Karuppusamy S. A review on trends in production of secondary metabolites from higher plants by in vitro tissue, organ and cell cultures. Journal of Medicinal Plant Research 2009;3(13), 1222-1239.

17. Lila K M. Valuable secondary products from in vitro culture, Secondary Products In Vitro. CRC Press LLC 2005

18. Payne G F, Shuler M L, Brodelius P. Plant cell culture. In: Large Scale Cell Culture Technology (ed. Lydensen B K), 
Hanser Publishers, New York, USA 1987;193-229.

19. Vijayasree N, Udayasri P, Aswani KY, Ravi B B, Phani KY, Vijay V M. Advancements in the Production of Secondary Metabolites. Journal of Natural Products,3, 2010;112-123.

20. Qi S Y, He M L, Lin L D, Zhang C H, Hu L J, Zhang H Z. Production of 2-(2-phenylethyl) chromones in cell suspension cultures of Aquilaria sinensis. Plant cell, tissue and organ culture 2005;83(2), 217-221.

21. Okudera Y, Ito M. Production of agarwood fragrant constituents in Aquilaria calli and cell suspension cultures. Plant Biotechnol 2009;26, 307-15.

22. Cogalniceanu G, Radu M, Fologea D, Moisoi N, Brezeanu A. Stimulation of tobacco shoot regeneration by alternating weak electric field. Bioelectrochemistry and Bioenergetics 1998;44(2), 257-260.

23. Munasinghe SP, Somaratne S, Weerakoon S R, Ranasinghe C. Prediction of chemical composition for callus production in Gyrinops walla Gaetner through machine learning. Information Processing in Agriculture 2020;7 (4), 511-522.

24. Jain S C, Pancholi B, Jain R.In-vitro callus propagation and secondary metabolite quantification in Sericostoma pauciflorum. Iranian Journal of Pharmaceutical Research 2012;11(4), 1103.

25. Kaimoyo E, Farag M A, Sumner L W, Wasmann C, Cuello J L, VanEtten H. Sub-lethal levels of electric current elicit the biosynthesis of plant secondary metabolites. Biotechnology Progress 2008;24(2), 377-384.

26. Cai Z, Riedel H, Saw N M M T, Kütük O, Mewis I, Jäger $H$, Smetanska I. Effects of pulsed electric field on secondary metabolism of Vitis vinifera L. cv. Gamay Fréaux suspension culture and exudates. Applied biochemistry and biotechnology 2011;164(4), 443-453

27. Ye H, Huang L L, Chen S D, Zhong J J. Pulsed electric field stimulates plant secondary metabolism in suspension cultures of Taxus chinensis. Biotechnology and bioengineering 2004;88(6), 788-795. 